\title{
End-customer value restructuring the financial service supply chain
}

\section{Introduction}

The increasing application of digital technology in all aspects of human life is shaping societies in many ways. This digital transformation has a profound impact on our ways to communicate, create and use knowledge and thus the choices we make. As consumers, our behaviour in the markets is impacted by this technology. In line with this development, the whole marketing landscape has changed significantly with the rise of digital technologies (e.g. Leeflang et al. 2014). In relation to this, there has been an increasing focus on services coupled with development in information and communication technologies (ICTs). Services have become a major productivity driver in advanced knowledge-based economies (Barrett et al. 2015). Rapid changes in the customer's buying behaviour, the increasing use of mobile devices, and international competition is forcing companies to digitalize their businesses as fast as possible. New phenomena such as big data, cloud services, mobile or omni-channels, and social media are accelerating the change. Globally, Uber, Airbnb and Amazon are well-known examples of the new services, novel business models and emerging opportunities provided by digitalization.

The banking sector has often been regarded as one of the early adopters of IT in terms of connecting their services and customers (Chemingui and Illaouna, 2013). Through digitalization, banking services providers have created new services for many years now, such as credit cards, automated teller machines, Internet and mobile banking, fund transfers, complex and synthetic securities, and credit default swaps (Nejad, 2016). Mobile banking has been beneficial for banks because they can provide their services in a more personalized and cost-efficient way (Riivari, 2005; Hoehle et al., 2012). It has been argued that customers can benefit using mobile banking since it can be more flexible, ubiquitous and convenient (Luarn and Lin, 2005; Wessels and Drennan, 2010).

Since banking and financial services have been regarded as somewhat ahead of other industries in the digitalized world, they are the first ones to deal with issues around it. In recent years, the banking sector has attempted to increase the value of their services to their customers but has struggled to understand what is a valuable service experience to its new digital-savvy customers. Banks are 
concerned that they are losing contact with their customers because of the banks' attitude and mind-set about digitalization: the organizations lack an interaction with their customers and therefore lack an understanding of the customers' value creation (Lähteenmäki and Nätti, 2013). Customer-centricity is an issue for banks because they are finding it difficult to understand ever-changing customers (Rajaobellion et al., 2013) and their daily needs (Heinonen et al., 2010; Grönroos and Voima, 2012). This is also supported by previous findings suggesting that potential customers are more interested whether mobile banking is compatible with their existing lifestyle and needs rather than with the usability and other functional aspects of the IT system as such (Ewe et al,. 2015). Additionally, technological advancement has led to the fact that digitalization has decreased personal interaction (Sandström et al., 2008).

The digitalization of banking services has created new challenges in building and maintaining valuable customer relationships. While Internet banking is a current trend amongst customers, they still feel that they are not gaining enough value from the services. According to Lähteenmäki and Nätti (2013), even the most innovative developments in the customer experience in retail banking are based on the idea that the customer has no other option than to participate in the bank's offerings in Internet banking. Typically, the service provider's own practices and processes are the primary objective for the business development (Vargo and Lusch, 2004; Heinonen et al., 2010), but in the changing retail banking, the customer is now becoming more and more in charge of deciding what kind of services are suitable in the future.

In order to provide new or improved digital services to customers, it is crucial to understand their total value experience. Value experience is not usually rational or objective but rather very personal and bounded in time and context (Corsaro and Snehota, 2010; Helkkula et al. 2012), yet customers' past experiences and future expectations also have a significant impact (Komulainen et al., 2013). Taking the customer-oriented perspective on value experience suggests that value is created by either the company, by the customer and company together, or by the customer alone (Heinonen et al. 2013). This perspective thus extends the traditional view of banking service value being based on the value defined by the service provider (value-in-exchange view) or being co-created in interaction with the service provider (see Grönroos, 2008; Vargo and Lusch, 2004) to emphasize value formed in the 
customer's own life context beyond the visible service interaction (Heinonen et al. 2013). Value may thus be formed through mental and invisible actions of the customer without any direct control by the bank (Medberg and Heinonen, 2014). As suggested by Medberg and Heinonen (2014), customeroriented perspective is needed to truly understand how value is formed for customers in banking services. Many researchers have studied the obstacles banks face when providing value to customers (Johnston, 1997; Lähteenmäki and Nätti, 2013; Mullan et al. 2017), but a few studies have tried to understand why customers feel the way they do about digital banking. Instead, substantial literature exists regarding mobile banking adoption in various cultural contexts (e.g. Akturan and Tezcan, 2012; Mullan et al., 2017; Shaikh and Karjaluoto, 2015).

While some researchers have predicted online banking as the 'better digital alternative' (Püschel et al., 2010), more and more researchers reveal the complications of mobile banking and its quick institutionalization (Laukkanen and Kiviniemi, 2010, Riivari, 2005). A need for further research in mobile banking has been put forward because of increasing customer mobility and new players in the financial service market (Kearney, 2012).

In addition to making sense of the interface that banks have with their customers, the digitalized market environment affects the networks that service providers operate in. The financial sector has witnessed the rise of the so-called Fintech companies, technology firms that provide services around activities that have traditionally been covered solely by banks. Along with this development, regulation has also started to be renewed. For example, in Europe, the EU's revised Payment Services Directive (PSD2) is set to accelerate the competition and digital disruption that are already reshaping the financial services industry across and beyond Europe. In a nutshell, it is regulating new forms of payment institutions, introducing new interaction models, and mandating the opening of banks' application programming interfaces (APIs) to third parties. This forces banks to make a key strategic decision: whether to become a banking 'utility' supporting other providers' customer-facing solutions, or an 'everyday bank' playing a central role in customers' daily lives. In the latter case, customer-centricity becomes a key issue.

However, the way these new service networks are organizing themselves currently represents many challenges for all actors in the market. We argue that restructuring of the service supply chain in 
the banking industry can be examined from the perspective of the end-customer value, as it forms the basis for all actors' value-creating activities.

The aim of the present study is to examine how the customer value experience conveys the restructuring of the service network in the banking industry. This paper contributes to previous research by examining customers' perceptions of the digital service experience. However, the main contribution relates to improving managerial practice in banking and financial sector as the study adopts a customercentric perspective and elaborates this into implications for service supply chain restructuring. The paper is structured as follows: First we discuss the existing theoretical foundations of service experience and customer value. Next, the empirical methodology of the research is explained in detail. The data will be analysed and discussed, and concluded with managerial implications while suggesting future research directions.

\section{Service network in banking industry}

In terms of the service supply chains in the financial markets, the emergence of financial technology (fintech) companies has disrupted the earlier rather focused and clear actor network structures of the supply market. Fintech is rapidly penetrating the financial markets by filling in the gaps left by the existing financial institutions by considerably improving the user experience. Even though bank sector has traditionally been walled by barriers of entry (e.g. laws and regulations) these barriers are fast eroding and banks face extensive pressure from the digital structural changes (Still et al. 2016). Thus, digital disruption has a twofold potential either to diminish the role and relevance of banks or to help them create better, more flexible and valuable services that could make them an even more important part of everyday life of their customers (Skan et al. 2015).

Haddad and Hornuf (2016) identify several areas that prior research has recently addressed in the field on fintech, including crowdlending, different types of crowdfunding, social trading platforms, robo-advisors, virtual currencies (e.g. Bitcoin or Ethereum), mobile payment and e-wallet services and venture capitalist investments in fintech start-ups. This huge variety of new services that have emerged describes well the diversity and extent of the turbulence banking industry currently faces. 
As digital disruption is still at the early phase, also fintech ecosystems or networks are just only emerging and taking forms. The roles of the different actors are thus unclear and nobody knows what they will be in the future. Still et al. (2016) found that in emerging fintech ecosystems no key or leading actor yet exists. Further, they speculated whether there even could be a focal company or could for example Apple, Google or Facebook "take over" also this arena. As a conclusion it was suggested that since fintech companies' main offerings are digital, easy-to-use financial services used either over mobile apps or internet browsers, radical innovations are not necessarily needed but one of the key questions will be the distribution channels used in the future.

As suggested by Skan et al. (2015), it is clear that the digital revolution in financial services is under way, but its impact on current banking players is not defined. In their study on future fintech and banking, they identify two scenarios for how digital revolution could affect the banks. Firstly, if banks are stuck with regulation and cost reduction, and continue with a product-based sales approach instead of improving the customer experience, they will compete for a shrinking share of wallet. On the other hand, according to the second scenario, if the banks' focus is on making customer's life easier and instead of asset monopolies, their customer insight grows and banks will be able to renew their business models to create more value for their customers. This is also in line with the study of Still et al. (2016) that suggests that in the core of the fintech ecosystem is the customer and a smooth experience of digital and seamless service for him/her. That is why adopting a customer-centric perspective on developing their future business models provides a critical starting point for the banks and aids in understanding the restructuring of the service network in the fast changing banking industry.

\section{Service experience and value}

The phenomenon of experience has been discussed by various scholars in service marketing (Addis and Holbrook, 2001; Sandström et al., 2008; Tronvoll et al., 2011). The need for deeper understanding of the role of the customer's experiences in marketing has emerged through the seminal article by Holbrook and Hirschman (1982), who noted that consumer behaviour has an experiential dimension (Tynan and McKechnie, 2009). Furthermore, Helkkula (2011) 
characterised the service experience as a process, an outcome and a phenomenon. Processbased experience is linked to experiential learning (Kolb, 1984; Edvardsson et al., 2005), outcome-based experience occurs when one element links various variables to several outcomes (Flanagan et al., 2005; Galetzka et al., 2006), and a phenomenological experience is promoted in consumer research (Holbrook and Hirschman, 1982; Arnould and Price, 1993; Meyer and Schwager, 2007) and in service-dominant (S-D) logic (Helkkula et al., 2012) as related to customer value. Consumers experience phenomena from their own perspective (Helkkula et al., 2012), and that automatically includes bringing one's past life experiences to new situations (Webster and Mertova, 2007). In this study, the emphasis is on the phenomenological perspective on service experience that emphasises especially the experiential nature of value (Helkkula et al., 2012).

The discussion around service experience is an important topic in marketing since companies are seeking to manage better customer experiences. However, in today's markets, the customers are not the only ones who share and co-create experiences of their interests in communities (Cova and Dalli, 2009, Schau et al., 2009), as interaction is also occurring in the service provider-customer dyads. The literature from customer's individual hedonic experience in direct or indirect contact with the provider (Meyer and Schwager, 2007, Verhoef et al., 2009) has now focused more on the collective experience of the consumers and service providers (Arnould and Price, 1993). That is why service providers collaborate with their network of suppliers and partners; each participant contributes to the customer's individual experience (Hakanen and Jaakkola, 2012, Tax et al., 2013). But to understand this experience in detail, companies need to understand how valuable their services are to their customers. Therefore, a concept of value needs to be explored in connection to experience.

Value has been studied extensively over the past decade in the field of marketing, much emphasizing the non-monetary aspects of customer perceived value. The two traditional 
dimensions of value are utilitarian and hedonistic, where the former takes place when a customer is considering the usefulness of a service, and the latter happens when they are considering the pleasant feelings and emotions that the service raised in them (Batra and Ahtola, 1991). Value is uniquely and phenomenologically defined by the service customers (Helkkula et al., 2012) because they experience value through their use of a certain service, which in turn is linked to their previous, current and even future imagined consumption experiences (Wikstrom, 2008). Therefore, the value proposed by the company does not always correspond with the customers' own approach to value (Heinonen, 2009; Grönroos and Helle, 2010).

Most of the previous studies have explored how customer perceives value from the service provider's offerings (Medberg and Heinonen, 2015), and have not focused on value in the experience in the broader context of customers' everyday lives (Helkkula et al., 2012). However, understanding customer value more profoundly and from the customer-centric perspective could provide important ways to differentiate a company's service offering from that of competitors (e.g., O'Loughlin et al., 2004; Roig et al., 2006; Strandberg et al., 2012). Nevertheless, as Roig et al. (2006) have noticed, few companies understand customer value in terms of how value can be delivered through experience and how to create services that consumers want. Helkkula and Kelleher (2010) analysed the cyclical inter-relationship between customer perceived value and customer service experience, and this dynamic relationship means that customers are always assessing and modifying their individual and collective 'lifeworlds', both consciously and unconsciously. The authors described the value perception process as a complex phenomenon that integrates the experiencing and perceiving value processes within a circle of phenomenological understanding. However, it should be remembered that customer perceived value is not exclusively related to the service provider's service offerings because customers make sense of their own service experiences (Helkkula 
and Kelleher, 2010). In other words, according to the customer-centric view, value can be created either by the company, by the customer and company together, or by the customer alone (Heinonen et al., 2013). Therefore, exploring value in the banking services not only in the direct interaction with the service provider but also within the customer's own everyday life context becomes highly important.

An attractive way to create a competitive edge in the banking sector is to enable value creation by the customers themselves and improve the customer experience (O'Loughlin et al., 2004) since customers create the final value (Grönroos, 2008, Heinonen et al. 2010). While banks are considering the generated value in the customer's life context, they most often miss that the customer's life and practices could be far ahead in the future. Lähteenmäki and Nätti (2013) believe that the future of retail banking will be changed due to regulation, competition and customer behaviour, and this will eventually force banks to focus on delivering an integrated and holistic value experience. Nejad (2016) has recommended that future research focuses on consumer studies because the topics other than adoption or resistance have decreased in recent years, which evidently entails more academic attention to the value research in the period of digital banking.

\section{Methodology}

Qualitative study is chosen as an appropriate research method with characteristics of phenomenological research strategy, which states that the participant's views and experience are considered as 'facts' (Helkkula et al., 2012). Empirical data was collected using focus groups and interviews in order to collect in-depth information from the participants about the phenomenon. Three focus groups were arranged in spring 2015. All focus groups had 4 participants, men and women, ages ranging from 23 to 31. Two to three researchers guided the discussions, and each discussion lasted about two hours. Before the focus groups, two individual pre-interviews were arranged to test the method. These two interviews also provided applicable data for the analysis. The invitation to participate in the research was sent using 
one of the researcher's Facebook pages, and all the volunteer participants were encouraged to sign up for the research. The focus groups were arranged on the university's premises, in a research lab for innovative methods. During the focus groups, the participants had an interactive discussion about future financial and payment habits. Before the discussion, their thinking was first enhanced with videos of unusual situations for payments, such as in a desert, in a spacecraft and in a bazaar, to let 'their minds fly'. In the second phase, a digital storytelling method was used, where each participant was able to describe their thoughts about their own financial and banking habits in the future by utilizing digital tools available in the research lab and sharing this story with the group. Additionally, the participants reflected on and talked about their everyday banking and financial services experiences.

Altogether 25 thematic interviews took place during spring 2015 (6 interviews) and spring 2016 (19 interviews). The duration of the interviews was between 24 and 55 minutes. The invitation to participate was sent again in the researchers' Facebook pages, and all of the volunteered participants were invited to participate in the study. The interviews had a slightly different goal than the focus groups, and they focused on the real users of digital banking services and the usage of mobile applications. The structure followed a semi-structured interview procedure because the researchers' goal was to gain an understanding of the participants' experiences of the phenomenon (Silverman, 2013). The ages of the participants varied from 20 to 64, and the majority of them were women.

All interviews and focus group sessions were recorded and transcribed verbatim. The total number of material amounted to 359 pages. Content analysis was used to analyse the data, adopting an abductive approach. Following Miles and Huberman (1994), the analysis was implemented through phases of data reduction, data display and drawing conclusions. NVivo 8 software was used to facilitate the content analysis and stimulate the researchers' interaction with the large amount of data.

\section{Findings}

The main findings of this study show that as customers experience banking services, they do not necessarily link this experience straight-forwardly as bank's financial services but rather in relations to a wider market context. Thus, the role of the bank in the customer's value experience is limited and dependent on the wider service supply chain. 
When examining the customer's value experience, it is evident that it is highly complex and entails both utilitarian and hedonistic aspects. Based on our data, the experience consists of different dimensions, one being the ease and speed of paying for products. This can be seen as a utilitarian reason to use the services, as participants appreciated the convenience of the use. As an example, one focus group participant said: 'When you have used your mobile as a payment method, you start to think that this is so easy, why haven't I done this before?' (Woman, 23 years). Those who used the specified mobile banking application also appreciated the ease of use and also its simplicity, free of charge locus and the possibility to follow the money flow and control spending and saving. The data showed that mobile banking is a big part of consumers' daily activities because it is a valuable service to complete the activities on a daily basis, as illustrated in the following quotation: 'That's why I actually like [the mobile banking app] because it's so fast, clear and easy to use. And it actually affects my everyday life and behaviour.' (Woman, 31 years).

In terms of bank's role in the customer's value experience, the analysis also indicated that participants did not receive a strong emotional experience from the digital services. Some of the hedonic reasons for using digital banking services were strongly linked to utilitarian reasons: ease and convenience increased their satisfaction, and complicated situations led to poor experiences. One participant even linked the service to her feelings: '... When they work well, they do not raise any feelings. It is just something that you do. But then again, if they don 't work, then I'm outraged.' (Woman, 37 years). There were no differences when asking how the experience made them feel, because it was considered to be the same with the service. This citation illustrates this situation: 'It's all about the functionality, that you need to be able to do something that used to be hard to do or took too much time.' (Man, 36 years). Thus, the role of banks was not considered as hedonically important in a person's life, although the value experience from using the services was embedded into the customer's broad context of everyday-life. This is evident also in the following quote, which addressed how banks can improve their digital banking services in the future: I have not even thought of that. You just assume that a bank's only purpose is to pay the bills.' (Woman, 36 years).

For understanding the connection between the customer's value perceptions of the service experience and its impact on the restructuring of the service supply chain, the data shows that there are 
multiple reasons why customers think that their service experience is disrupted, and these reasons are more or less related to the lack of coordination between the service providers. For example, reliable global payment methods and the connections between different banks and financial institutions were particularly important for safe and convenient payments. The value factor is seen as how the banks could change their services to be more customer-friendly. To clarify, participants would appreciate if EFTPOSs in retail outlets would be similar internationally, and in order to receiving money transfers faster, the banks' networks would work faster and more efficiently. The following citation from a focus group illustrates this: 'If you could make the systems between banks similar so that you wouldn't have to wait for weeks [for transfers] and then pay a terrible price for waiting for them.' (Woman, 21 years). Furthermore, those who used the specified mobile banking application valued that in the future the payments would be automated, and the individual should not be focusing on 'paying at all'. For example, a man illustrated this idea: '[E-bills] would all be direct bills and I would not have to personally worry whether I have paid that bill... so that I could trust that bills would be paid automatically [from the application].' (Man, 29 years). Thus, to overcome what customer's experienced as disruptions in their value experience, multiple actors in the service supply chain would need to be considered, not only one actor, like a bank.

Finally, the banking industry is also segregated by the exclusion of other industries and their networks. According to the data, some industries already work well with the banking supply chains, such as retailing. Many of the specified mobile banking application users even said they use the app when they are at the retail point of sale: 'When I'm at the store and before I pay, I check [the app].' (Woman, 31 years). Additionally, the majority of participants accepted targeted marketing from retailers if they received personalized deals and vouchers, which is linked to the utilitarian reasons to use the mobile app. For example, the following participant explains why she would share her data with service providers: 'Yeah, targeted marketing I think. That's the most essential thing. So that you see where you spent your money and how much you spent at this store this month, so here is something for you. So something that is personally offered to you...' (Woman, 31 years).

In addition to cross-industry context, the customers' value experiences were also related to global context. To experience a smooth value processes, global services were raised in our data, as 
highlighted by this participant who uses the specified banking app: 'Obviously, I hope that if similar services can be found abroad, then I could feed the data there too. Like with cooperation I could use this in the 'digital jungle' between companies regardless in which country it is located.' (Woman, 31 years). The integration of service providers is something that the participants saw as important since there are more and more digital services available. Instead of creating new digital channels (e.g. mobile applications or websites) the users would like to see fewer of them and more data in one place: 'For example, the council things could be like that. Library cards and health services... and others could be on one mobile application. And not like I need to get separate apps for all of them.' (Woman, 32 years). Conversely, while the data suggests that incorporating services is the future of digital services, there are still doubts that personal security might be reached. This is an especially important issue for banks because according to the data, customers trust their banks. Therefore, there might be other solutions to banking like other forms of money and payment, as illustrated by this comment: 'That's what it's about today - these networks will be integrated, so it's kind of a loss of your personal security, so that's why I find bitcoins very interesting.' (Man, 31 years).

Based on our empirical analysis, to provide superior value experience, a multitude of actors in the whole service supply chains, or service ecosystems more broadly, need to be involved and aligned.

\section{Discussion}

The present study shows that customers defined the value by themselves through the use of the services that they used in their everyday life (Helkkula et al., 2012). This means that customer service experience should be the driver of the banking service supply chain. Based on our data, customers do not necessarily perceive banks as value providers as such when they use the services, but they are more concerned with the services as a way to improve their life. Examining the value related to the service experiences revealed that customers were not showing commitment to the service providers or their brand, but they were more concerned with the way the services advanced their own ways of life. That is why the value proposed or offered by the banks do not necessarily equal the customer's perception of value (c.f. Heinonen, 2009; Grönroos and Helle, 2010). Thus, our results support and extend findings of Ewe et al. (2015) who found that for consumers it is important that mobile banking complement their 
lifestyles. Considering the restructuring of the service supply chain, this raises the question of whether in the future the digitalized banking services will be based on established customer-service provider relationships between consumers and banks, or whether the customer interface will be based on some other relationship, such as customer and technology, for example. This could be something similar as we have with smartphones in relation to different operating systems used by the brands.

The present research also revealed that digital services have their complications, which has been noticed by other authors as well (Kleijnen et al., 2004; Riivari, 2005). While the ideal situation might be one in which the bank provides the ultimate experience and good value for its customers, it seems that delivering the service that consumers want is disrupting the value in the experience (e.g. Roig et al., 2006). Our data revealed that digital banking services offered more utilitarian than hedonic value to end-customers. The usefulness of the services rather than the pleasant feelings and emotions that were raised using the service (Batra and Ahtola, 1991) were more emphasized in the findings and could be leading to value disruption of the customer service experience because the services should raise both utilitarian and hedonic reasons to use the services. In relation to service supply chain restructuring, this further indicates that the role of customer loyalty in bank-customer relationships is not very high, and that might not be the cornerstone of the whole chain.

Overall, the disconnection between different banks and other actors in the financial services market were a common theme that was raised. Consumers often do not see banks separately, but they are more concerned about the services as one network that should be linked to all spheres of their daily life. In fact, it seemed that if the banks do not open their networks more widely, the customer value may be disrupted. Our findings extend the views of Ewe et al. (2015) who suggested that consumers value multiple types of transactions available through mobile banking, such as paying movie or airline tickets. That is why service providers should collaborate with their network of suppliers and partners so that each participant could contribute to the customer's individual experience (Hakanen and Jaakkola, 2012, Tax et al., 2013). After all, the end-consumers decide what is valuable to them, and they do so by experiencing the services and comparing them to their previous, current and future imagined consumption experiences (Wikstrom, 2008). Lähteenmäki and Nätti (2013) predicted that the future of banking should focus on customer behaviour because that would force banks to focus on delivering an 
integrated and holistic value (in experience). This point is crucial from the service supply chain point of view-it is unlikely that such a holistic value can be provided by a single banking service provider alone because the ecosystem around such services is becoming more and more complex.

\section{Conclusion and managerial implications}

The aim of the present study was to examine how the customer value experience conveys the restructuring of the service network in the banking industry. To achieve this, the paper outlined an approach to examining customers' experiences in digital banking services. It also analysed the implications of these experiences for the way service providers should integrate their networks to improve the end-customer's service experience in a way that would be the most valuable to them. The complex connection between value and service experience prompts a transition in marketing practices for a variety of businesses across industries and markets, such as business-to-consumer and businessto-business.

The present paper contributes to value research and especially to the discussion in service experiences by addressing some of the disruptions happening at the industry level. The paper shows that the focus should be on customer value because banks should understand that their services are not enough for the customers - they are only seen as banks, not as providers of the holistic value that is required from the customer's point of view. The purpose of the services should be to support the daily life of a customer, which brings them the value they experience. The 'bank' experience lies in the fact that customers can pay for purchases easily, the various different delivery options from online orders, the easily reachable customer e-service and many more services that are linked to banks' services. When banks realize their rather limited direct role in customer experience, they will understand what customers want, why they buy and pay, as well as why they need banks' services to enable their experiences.

The results of the present study call for further research especially in terms of the network and partnership formation within the banking industry. Some actors have put forward their own start-up incubators in the hope of gaining access to technological innovations. Yet the logic of creating the new ecosystem and related network remains unclear, and it is integral to examine how technology providers 
and banking services providers are coming together to provide a holistic value experience to endcustomers. Furthermore, our research puts forward the need to examine the value disruption-how customer value disruption takes place in the context of banking services. As our data indicated, the lack of a holistic view from the service providers' perspective disrupted the value perception of the endcustomer. However, the processes and factors related to this would be important to reveal to develop an understanding towards avoiding this.

From a managerial perspective, research from the B2B perspective on digitalization could help to understand its effect on mobile banking value. Therefore, we also encourage future researchers to investigate the underlying reasons that hinder service providers from integrating their services further to provide value to the end-customer. Customer value makes it a must to change the bank's network, and together, the contributions of this study and the research around service experience creating value can pave the way for a better understanding of its future development.

\section{References:}

Akturan, U. and Tezcan, N. (2012), "Mobile banking adoption of the youth market. Perceptions and intentions", Marketing Intelligence and Planning, Vol. 30, No. 4, pp. 444-459.

Addis, M. and Holbrook, M. B. (2001), "On the conceptual link between mass customization and experiential consumption: An explosion of subjectivity", Journal of Consumer Behaviour, Vol. 1, No. 1, pp. 50-66.

Arnould, E.J. and Price, L.L. (1993), "River magic: extraordinary experience and the extended service encounter", Journal of Consumer Research, Vol. 20 No. 1, pp. 24-45.

Barrett, M., Davidson, E., Prabhu, J. and Vargo, S. (2015). Service innovation in the digital age: Key contributions and future directions, MIS Quarterly, Vol. 39 No. 1 pp. 135-15.

Batra, R., \& Ahtola, O. T. (1991). Measuring the hedonic and utilitarian sources of consumer attitudes. Marketing Letters, Vol. 2 No, 2, pp. 159-170.

Chemingui, H. and Iallouna, H. B. (2013), "Resistance, motivations, trust and intention to use mobile financial services", International Journal of Bank Marketing, Vol. 31 No. 7, pp. 574-592.

Corsaro, D. and Snehota, I. (2010). "Searching for relationship value in business markets: Are we missing something?" Industrial Marketing Management, Vol. 39 No. 6, pp. 986995.

Cova, B. and Dalli, D. (2009), "Working consumers: the next step in marketing theory?", Marketing theory, Vol. 9 No. 3, pp. 315-339.

Edvardsson, B., Enquist, B. and Johnston, R. (2005), "Cocreating customer value through hyperreality in the prepurchase service experience", Journal of Service Research, Vol. 8 No. 2, pp. 149-61.

Ewe, S.Y., Yap, S.F., Lee, C.K.C. (2015). "Network externalities and the perception of innovation characteristics: mobile banking", Marketing Intelligence and Planning, Vol. 33 No. 4, pp. 592-611. 
Flanagan, P., Johnston, R. and Talbot, D. (2005), "Customer confidence: the development of a 'pre-experience' concept", International Journal of Service Industry Management, Vol. 16, Nos 3/4, pp. 373-84.

Galetzka, M., Verhoeven, J.W.M. and Pruyn, A.T.H. (2006), "Service validity and service reliability of search, experience and credence services", International Journal of Service Industry Management, Vol. 17 No. 3, pp. 271-83.

Grönroos, C. (2008), "Service logic revisited: who creates value? And who co-creates?", European Business Review, Vol. 20 No. 4, pp. 298-314.

Grönroos, C. and Helle, P. (2010), "Adopting a service logic in manufacturing", Journal of Service Management, Vol. 21 No. 5, pp. 564-590.

Grönroos, C. and Voima, P. (2012) Critical service logic. Making sense of value creation and co-creation. Journal of the academy of marketing science. Vol. 41, No. 2, pp. 133-150.

Haddad, C. and Hornuf, L. (2016), "The emergence of the global fintech market: Economic anf technological determinants", CESifo Working Paper Series No. 6131, August 25, 2016.

Hakanen, T. and Jaakkola, E. (2012), "Co-creating customer-focused solutions within business networks: a service perspective", Journal of Service Management, Vol. 23 No. 4, pp. 593-611.

Helkkula, A. (2011). Characterising the concept of service experience. Journal of Service Management, Vol. 22 No. 3, pp. 367-389.

Heinonen, K. (2009), "The influence of customer activity on e-service value-in-use," International Journal of Electronic Business, Vol. 7 No. 2, pp. 209-214.

Heinonen, K., Strandvik, T., Mickelsson, K.-J., Edvardsson, B., Sundström, E., \& Andersson, P. (2010). A customer-dominant logic of service. Journal of Service Management, Vol. 21 No. 4, pp. 531-548.

Heinonen, K., Strandvik, T. and Voima, P. (2013), "Customer dominant value formation in service", European Business Review, Vol. 25 No. 2, pp. 104 - 123.

Helkkula, A. (2011). "Characterising the concept of service experience", Journal of Service Management, Vol. 22 No. 3, pp. 367-389.

Helkkula, A., Kelleher, C., \& Pihlström, M. (2012). "Characterizing value as an experience: Implications for service researchers and managers", Journal of Service Research, Vol. 15 No. 1.

Hoehle, H., Scornavacca, E. and Huff, S. (2012), "Three decades of research on consumer adoption and utilization of electronic banking channels: a literature analysis", Decision Support Systems, Vol. 54 No. 1, pp. 122-132.

Holbrook, M.B. and Hirschman, E.C. (1982), "The experiential aspects of consumption: consumer fantasies, feelings, and fun", Journal of Consumer Research, Vol. 9 No. 2, pp. 132-42.

Johnston, R. (1997), "Identifying the critical determinants of service quality in retail banking: importance and effect", International Journal of Bank Marketing, Vol. 15 No. 4, pp. $111-16$.

Kearney, A.T. (2012), "Inside tomorrow's retail bank", (White Paper).

Kleijnen, M., de Ruyter, K. and Wetzels, M. (2004), "Consumer adoption of wireless services: discovering the rules, while playing the game", Journal of Interactive Marketing, Vol. 18 No. 2, pp. 51-61.

Kolb, D.A. (1984), Experiential Learning: Experience as the Source of Learning and Development, Prentice-Hall, Englewood Cliffs, NJ.

Komulainen, H., Mainela, T. and Tähtinen, J. (2013). "Customer's potential value: the role of learning”, Journal of Business Marketing Management, Vol. 6 No. 1, pp. 1-21.

Laukkanen, T. and Kiviniemi, V. (2010), "The role of information in mobile banking resistance”, International Journal of Bank Marketing, Vol. 28, No. 5, pp. 372-388.

Lähteenmäki, I. and Nätti, S. (2013), "Obstacles to upgrading customer value-in-use in retail banking", International Journal of Bank Marketing, Vol. 31 Issue 5 pp. 334 - 347.

Leeflang, P., Verhoef, P., Dahlström, P. and Freundt, T. (2014), "Challenges and solutions for marketing in a digital era", European Management Journal, Vol. 32 No. 1, pp. 1-12. 
Luarn, P. and Lin, H.H. (2005), "Toward an understanding of the behavioral intention to use mobile banking", Computers in Human Behavior, Vol. 21 No. 6, pp. 873-891.

Meyer, C. and Schwager, A. (2007), "Understanding customer experience", Harvard Business Review, Vol. 85 No. 2, pp. 116-126.

Mullan, J., Bradley, L. and Loane, S. (2017), "Bank adoption of mobile banking: stakeholder perspective", International Journal of Bank Marketing, Vol. 35 No. 7, pp. 1152-1172.

Nejad, M. (2016), "Research on financial services innovations", International Journal of Bank Marketing, Vol. 34 No. 7, pp. 1042-1068.

O’Loughlin, D., Szmigin, I. and Turnbull, P. (2004), "From relationships to experiences in retail financial services", International Journal of Bank Marketing, Vol. 22 No. 7, pp. 522539.

Rajaobellion, L., Brun, I. and Toufaily, E. (2013), "A relational classification of online banking customers", International Journal of Bank Marketing, Vol. 31 Iss: 3, pp.187-205.

Riivari, J. (2005). "Mobile banking: A powerful new marketing and CRM tool for financial service companies all over Europe", Journal of Financial Services Marketing, Vol. 10 No. 1, pp. 11-20.

Roig, J.C.F., Garcia, J.S., Tena, M.A.M. and Monzonis, J.L. (2006), “Customer perceived value in banking services", International Journal of Bank Marketing, Vol. 24 No. 5, pp. 266283.

Sandström, S., Edvardsson, P., Kristensson, P. and Magnusson, P. (2008), "Value in use through service experience", Managing Service Quality: An International Journal, Vol. 18 Iss 2 pp. 112-126.

Shaikh, A. A. and Karjaluoto, H. (2015), "Mobile banking adoption: A literature review", Telematics and Informatics, Vol. 32 No. 1, pp. 129-142.

Schau, H.J., Muñiz, A.M. Jr and Arnould, E.J. (2009), "How brand community practices create value", Journal of Marketing, Vol. 73 No. 5, pp. 30-51.

Silverman, D. (Ed.) (2013), "Issues in research design", in Doing Qualitative Research: A Practical Handbook, SAGE Publications Inc., Thousand Oaks, CA, pp. 43-68.

Skan, J., Dickerson, J. and Masood, S. (2015), The future of fintech and banking: digitally disrupted or reimagined? Accenture, London.

Still, K., Huhtala, T., Saraniemi, S. (2016), "FinTech as business and innovation ecosystems", in Proceedings of ISPIM Innovation Summit, Kuala Lumpur, Malaysia. The International Society for Professional Innovation Management (ISPIM): 4-7 December 2016. International Society for Professional Innovation Management's Innovation Conference, 1 January.

Strandberg, C., Wahlberg, O. and Ohman, P. (2012), "Challenges in serving the mass affluent segment: bank customer perceptions of service quality", Managing Service Quality, Vol. 22 No. 4, pp. 359-385.

Tax, S.S., McCutcheon, D. and Wilkinson, I.F. (2013), “The service delivery network (sdn): a customer-centric perspective of the customer journey", Journal of Service Research, Vol. 16 No. 4, pp. 454-470.

Tronvoll, B., Brown, S.W., Gremler, D.D. and Edvardsson, B. (2011), "Paradigms in service research", Journal of Service Management, Vol. 22 No. 5, pp. 560-85.

Tynan, C. and McKechnie, S. A. (2009), "Experience marketing: A review and reassessment," Journal of Marketing Management, Vol. 25 Nos. 5/6, pp. 501-517.

Vargo, S.L. and Lusch, R.F. (2004), "Evolving to a new dominant logic for marketing", Journal of Marketing, Vol. 68 No. 1, pp. 1-14.

Verhoef, P.C., Lemon, K.N., Parasuraman, A., Roggeveen, A., Tsiros, M. and Schlesinger, L.A. (2009), "Customer experience creation: determinants, dynamics and management strategies", Journal of Retailing, Vol. 85 No. 1, pp. 31-41.

Webster, L. and Mertova, P. (2007), Using narrative inquiry as a research method: An introduction to using critical event narrative analysis in research on learning and teaching. Routledge, Cornwall.

Wessels, L. and Drennan, J. (2010), "An investigation of consumer acceptance of M-banking", International Journal of Bank Marketing, Vol. 28 No. 7, pp. 547-568. 
Wikstrom, S. (2008), “A Consumer Perspective on Experience Creation”, Journal of Customer Behaviour, Vol. 7, No. 1, pp. 31-50. 